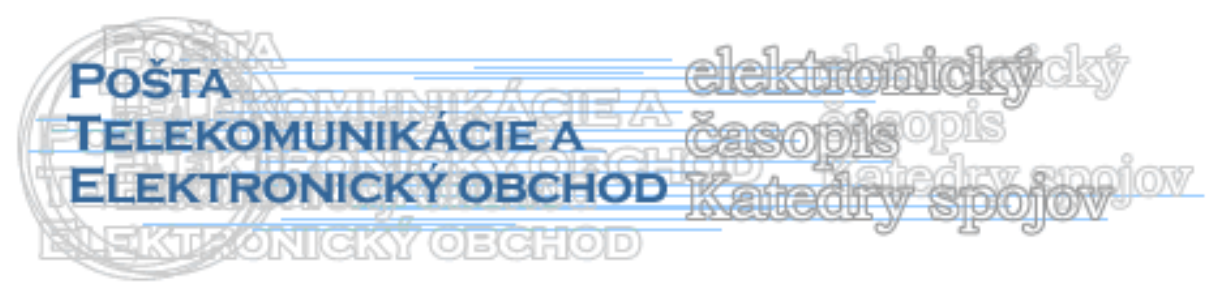

\title{
ELEKTRONICKÉ SLEDOVANIE A OCHRANA MAJETKU V MALOOBCHODE
}

\author{
Ondrej Maslák*, Juraj Vaculík**
}

\section{Úvod}

Článok sa zaoberá majetkovou kriminalitou v maloobchode a možnostiam využitia rádiofrekvenčnej komunikácie ako ochrany pred krádežou. Využite ochrany majetku pomocou RFID sa používa aj $\mathrm{v}$ súčasnosti, ale potenciál celej technológií $\mathrm{v}$ spojení s centrálnymi databázami je do budúcnosti omnoho väčší.

\section{Majetková kriminalita v maloobchode}

Strata a znehodnotenie majetku v rámci maloobchodu má niekol'ko príčin. Nie všetok vyrobený tovar sa nakoniec podarí predat' koncovému spotrebitel'ovi. Určité percento majetku je poškodené pri dodávaní, skladovaní alebo manipulácií v skladoch. Aj napriek vysokému stupňu automatizácie v skladovom hospodárstve vel'ká čast' vyskladňovania a manipulácie s tovarom podlieha l'udskému faktoru. Strata majetku môže byt' spôsobená chybnými objednávkami v rámci administrácie a podobne. Ked' už sa tovar dostal bezpečne do predajne nie je zaručené, že predajňu opustí až po jeho zaúčtovaní a zaplatení pretože d'alším signifikantným faktorom straty majetku sú krádeže.

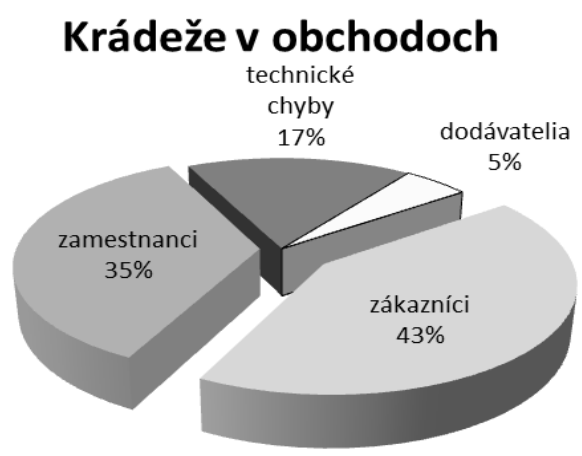

Obrázok 1. Krádeže v maloobchode za rok 2010 [zdroj: http://www.tyden.cz/rubriky/byznys/cesko/v-obchodech-se-kradlo-meneale-stale-jsme-na-spici-eu_184245.html]

\footnotetext{
* Ing. Ondrej Maslák, Žilinská Univerzita v Žiline, katedra spojov NF300, tel.: +421902643078, e-mail: ondrej.maslak@fpedas.uniza.sk

** Doc. Ing. Juraj Vaculík., Žilinská Univerzita v Žiline, katedra spojov NF439, e-mail: juraj.vaculik@fpedas.uniza.sk
} 
V roku 2011 podl'a štatistík krádeží v obchodoch Európy ukradli dohromady tovar za 86 miliárd EUR. Najviac sa ukradlo k pomeru k tržbám v Českej republike. Slovensko skončilo na šiestom mieste.

Tabul'ka 1. Podiel ukradnutého tovaru k tržbám[zdroj: Britské Centrum pre výskum obchodu]

\begin{tabular}{|l|l|l|l|}
\hline & $\begin{array}{l}\text { Podiel z tržieb v } \\
\text { percentách }\end{array}$ & $\begin{array}{l}\text { Hodnota tovaru } \\
\text { v miliónoch } €\end{array}$ & $\begin{array}{l}\text { Nárast oproti roku } \\
\mathbf{2 0 1 0} \text { v percentách }\end{array}$ \\
\hline Česko & 1,53 & 386 & 9,3 \\
\hline Pobaltie & 1,5 & 215,7 & 7,1 \\
\hline Mad'arsko & 1,48 & 363,2 & 7,2 \\
\hline $\begin{array}{l}\text { Belgicko } \\
\text { Luxembursko }\end{array}$ & 1,47 & 890 & 6,6 \\
\hline Slovensko & 1,46 & 145 & 6,6 \\
\hline Írsko & 1,43 & 467,8 & 8,3 \\
\hline Pol'sko & 1,41 & 1220 & 4,4 \\
\hline
\end{tabular}

Vývoj škôd spôsobených majetkovou kriminalitou. Do týchto štatistických údajov patria všetky druhy kriminálnej majetkovej činnosti. K ich predchádzaniu alebo zmierneniu nie je samozrejme vždy možné použit' RFID technológiu. Niektoré prípady sú vhodnejšie ako napríklad ochrana majetku v maloobchode alebo zabezpečenie perimetra pomocou RFID aktívnych štítkov umiestnených na plote alebo bránach pozemku ktorý majú chránit'. Opät', tak ako to je aj v maloobchode, ochrana majetku je najlepšia v kombinácií technológií. Preto je najvhodnejším doplnkom perimetrickej ochrany plotov práve CCTV technológia. Škody spôsobené majetkovou kriminalitou majú klesajúci charakter od roku 2005.

Tabul'ka 2. Majetková kriminalita a jej škody za vybrané obdobie na Slovensku [ Zdroj: http://portal.statistics.sk/showdoc.do?docid=13842]

\begin{tabular}{|c|c|c|c|c|c|c|c|c|}
\hline & $\mathbf{2 0 0 4}$ & $\mathbf{2 0 0 5}$ & $\mathbf{2 0 0 6}$ & $\mathbf{2 0 0 7}$ & $\mathbf{2 0 0 8}$ & $\mathbf{2 0 0 9}$ & $\mathbf{2 0 1 0}$ & $\mathbf{2 0 1 1}$ \\
\hline $\begin{array}{c}\text { Škody } \\
\text { v miliónoch } \\
€\end{array}$ & 146,8 & 148,5 & 145,2 & 140,3 & 130,2 & 122,9 & 108,7 & 96,7 \\
\hline
\end{tabular}

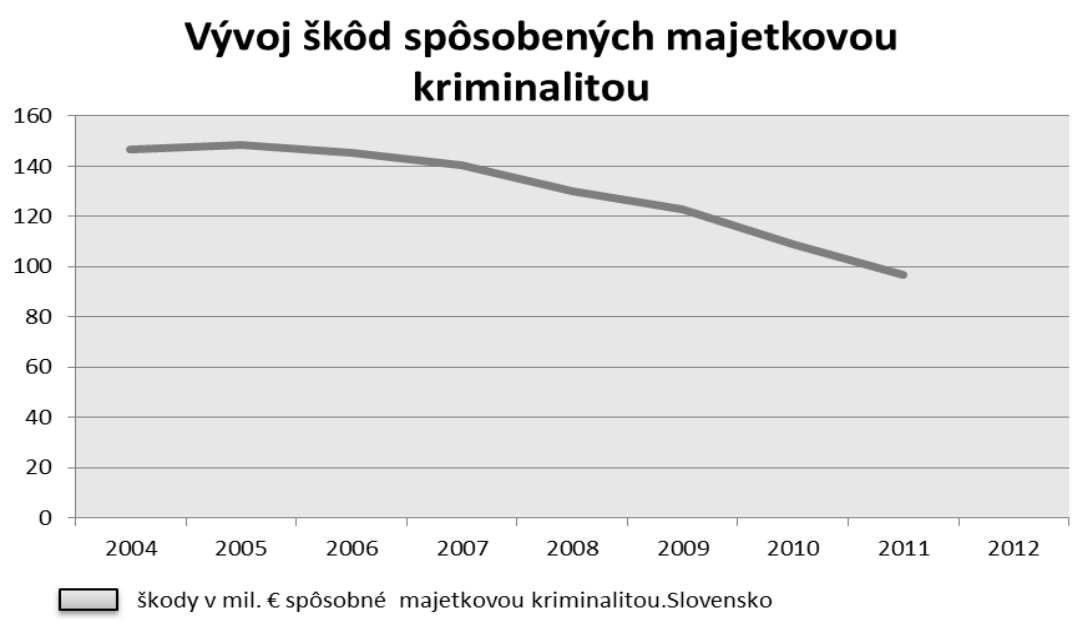

Obrázok 2. Vývoj škód vlastné spracovanie podl’a [Zdroj: http://portal.statistics.sk/showdoc.do?docid=13842] 


\section{Spôsoby ochrany majetku v maloobchode} majetku.

Najpoužívanejšie bezpečnostné systémy v obchodných predajniach na ochrane

- EAS (Electronic Article Surveillance)

- slučková ochrana

- prekážky, nedostupnost'

- atrapy, makety

- kamerové systémy (CCTV)

- ochranka, súkromné bezpečnostné služby

Takmer nikdy sa vo vel'kokapacitných predajniach nepoužíva len jeden druh ochrany majetku. Najefektívnejší spôsob je kombinácia hore uvedených bezpečnostných systémov.

\section{Súčasný stav}

Maloobchod a predajne využívajú RFID technológiu ako indikáciu či označený produkt opustil alebo neopustil predajňu bez zaplatenia. Vyplýva to z konštrukcie jednobitových štítkov, ktoré nadobúdajú len dva stavy bud' je aktívny(nezaplatený) alebo deaktivovaný(zaplatený). Deaktivácia sa uskutočňuje bud' fyzickým odobratím štítku z tovaru, alebo jeho znehodnoteným pomocou silného magnetu pri pokladni. Existujú rôzne druhy RFID štítkov operujúcich v rôznych frekvenčných pásmach. Najbežnejšie sú RFID štítky operujúce v pásme 13,56 Mhz.

\section{EPC- Elektronický produktový kód}

EPC je elektronický produktový kód. Tento kód jednoznačne a univerzálne označuje tovar alebo akýkol'vek objekt. Bol vytvorený v centre MIT Auto-Id. Už z pomenovania vyplýva, že ide o elektronickú formu identifikácie. Č́́slo je zakódované a uložené napríklad na štítok. Pomocou tohto unikátneho kódu je možné označit' každú jednu vec, výrobok individuálne a jedinečne. Udel'ovanie jednotlivých čísiel má na starosti EPC global, ktorý spadá pod neziskovú organizáciu GS1. Bez autorizácie tejto organizácie nie je možné dostat' a využívat' EPC kód. Týmto sa zabezpečí unikátnost' a bez kolíznost' pridel'ovaných čísiel . Ćíslo samo o sebe nemá žiadny zmysel pokial' nie je prepojene s databázou. EPC ako unikátny klúǔč dovolí pristupovat' k údajom o konkrétnom výrobku, ktoré sú uložené v databázach. [1]

Prečo použit' EPC? Základná otázka by mohla zniet' prečo neponechat' súčasný systém označovania pomocou čiarových kódov. Klasické čiarové kódy používané v maloobchode napríklad EAN_13 majú menšiu kapacitu oproti EPC kódu, ktorý má priestor aj na sériové číslo. Tak ako je to demonštrované na obrázku nižšie. 


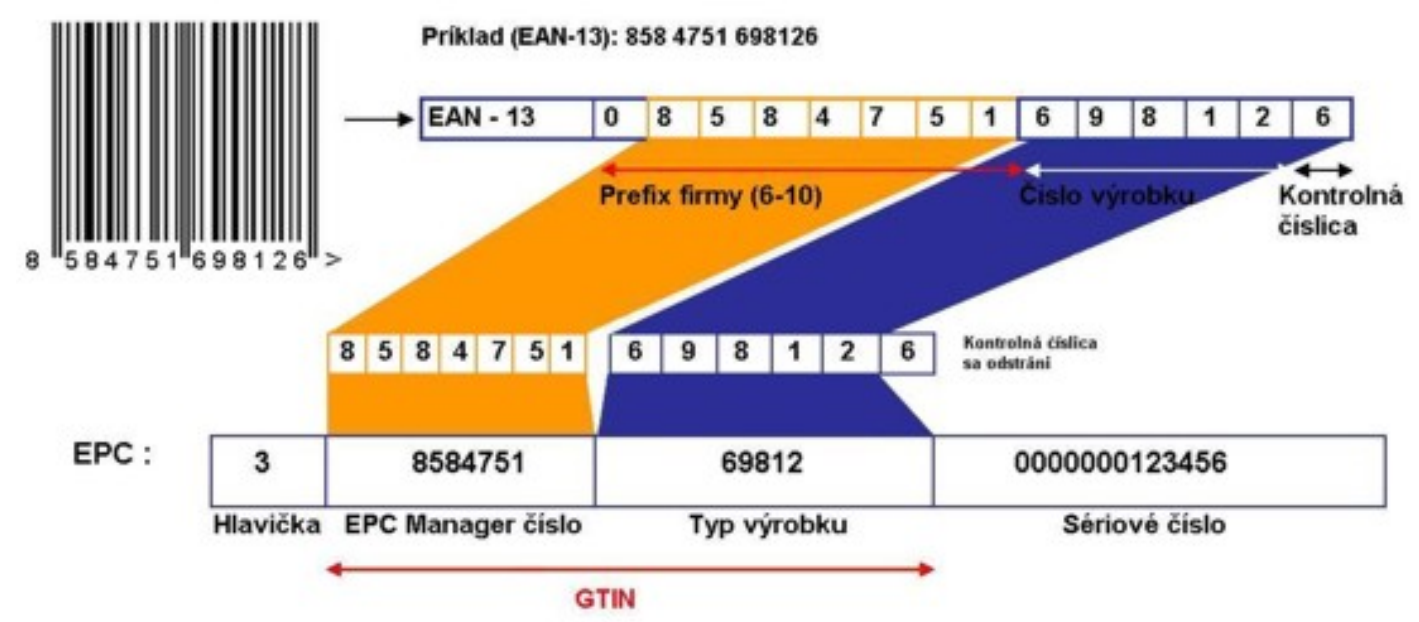

Obrázok 3. Príklad včlenenia GTIN do EPC ( Zdroj:EPC [online]. 2012. [Cit. 2012-01-03]. Dostupné na internete: <http://www.gs1sk.org/elktronicky-produktovy-kod >)

\section{Zloženie EPC}

- $\quad$ Hlavička- určuje nám typ EPC kódu pre každé z typov identifikačných označení je iná 8bitová kombinácia.

- $\quad$ EPC Manager číslo- prefix firmy a pridelené číslo od GS1- GS1 prefix firmy.

- $\quad$ Druh výrobku- druh výrobku ako skupina nejedná sa o konkrétne označenie výrobku.

- Sériové číslo- toto číslo označuje každý jeden výrobok samostatne nie len druh, môžu sa tu nachádzat' dodatkové informácie o výrobku.[1]

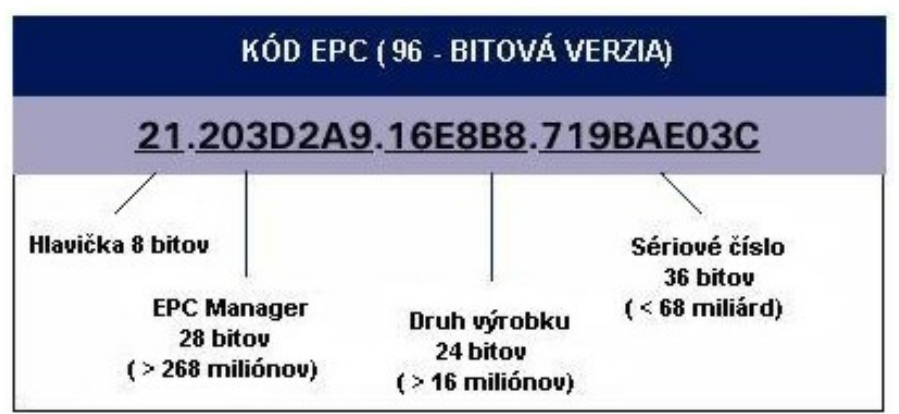

Obrázok 4. EPC kód (Zdroj: EPC [online]. 2012. [Cit. 2012-01-03]. Dostupné na internete: < http://www.gs1sk.org/elektronicky-produktovy-kod>)

Pri použití 96 bitovej verzie nám ako koncovému výrobcovi ostáva 36 bitov ktoré nie sú alokované. Povinné polia sú hlavička a EPC manažérske číslo. Nasledované druhom výrobku. Z jednoduchej kombinatoriky vyplýva, že máme k dispozícií $2^{\wedge} 24$ kombináciu druhov výrobkov čo je 16.777.216. Relatívne vysoký počet výrobkov a z každého výrobku sme jedinečne schopný označit’ $2 \wedge 36$ čo je 68.719.476.736. To pri kapacite štítka 96 bitov $\mathrm{k}$ dispozícií sú aj iné 195bitové. Keby sme splnili potrebné polia ako je hlavička( 8 bitov), EPC manager číslo (28 bitov) a ponechali by sme aj 24 bitov pre druh výrobku tak na sériové číslo máme k dispozícií 135 bitov a teda 4,3556142965880123323311949751266e+40. Niektoré kombinácie sa môžu časom vrátit’ spät' do obehu, ked' nehrozí kolízia s rovnakými číslami na súčasných výrobkoch. 
Každá jedna položka označená jedinečným EPC identifikátorom sa dá následne vyhl'adat' v centrálnej databázy. Centrálna databáza môže obsahovat' l'ubovol'né informácie o tovare. Dátum spotreby, výrobcu, krajinu pôvodu, prakticky čokol'vek čo je zaujímavé pre koncového užívatel'a a potrebné pre predajcu. Jednou z užitočných položiek by bol stav tovaru. Stav tovaru by indikoval či sa nachádza v predajni alebo nie, inak povedané či je zaplatený alebo sa má spustit' alarm pri jeho vynesení z prevádzky. V tomto riešení teda nedôjde $\mathrm{k}$ znehodnoteniu RFID štítka ako doteraz. RFID štítok ostáva aktívny len jeho stav v databáze sa zmení z nepredaného na predaný. Štítok nad’alej ostáva v prevádzke a je ho možné prečítat' pre získanie d’alších informácií požadovaných zákazníkom.

Rozšírenie: Potenciál RFID technológie je ale omnoho väčší ako používanie jednobitových štítkov a môže byt' súčast'ou komplexnejšieho celku. RFID štítok môže byt' nosičom pre omnoho väčšiu kapacitu pamäte ako je len jeden bit. K dispozícií sú 96bitové, 195bitové, 205 a viac bitové pamäte. K dispozícií máme dostatočnú kapacitu pamäte aby sme zapísali na štítok potrebné informácie. Čo sú ale potrebné informácie? Ked’že chceme zlepšit' súčasný systém potrebujeme minimálne zachovat' jeho doterajšiu funkčnost' a to bola ochrana majetku proti jeho vyneseniu bez zaplatenia z prevádzky. Na toto nám stačila hodnota jedného bitu ktorý sme mohli ,prepínat““ do dvoch polôh. V tomto systéme máme k dispozícií dostatok pamäte, aby sme mohli každý jeden výrobok, knihu, šatstvo označit' jedinečným identifikátorom. Jedinečný identifikátor nám zaručuje že každá položka ním označená bude jednoznačne rozpoznatel'ná medzi ostatnými. Pre dosiahnutie bez kolíznosti jedinečných identifikátorov od rôznych výrobcov a dodávatel'ov musí existovat' nejaká riadiaca autorita. Úlohu takejto autority preberá v dnešnej dobe organizácia GS1 a jej systém označovania pomocou EPC kódov.

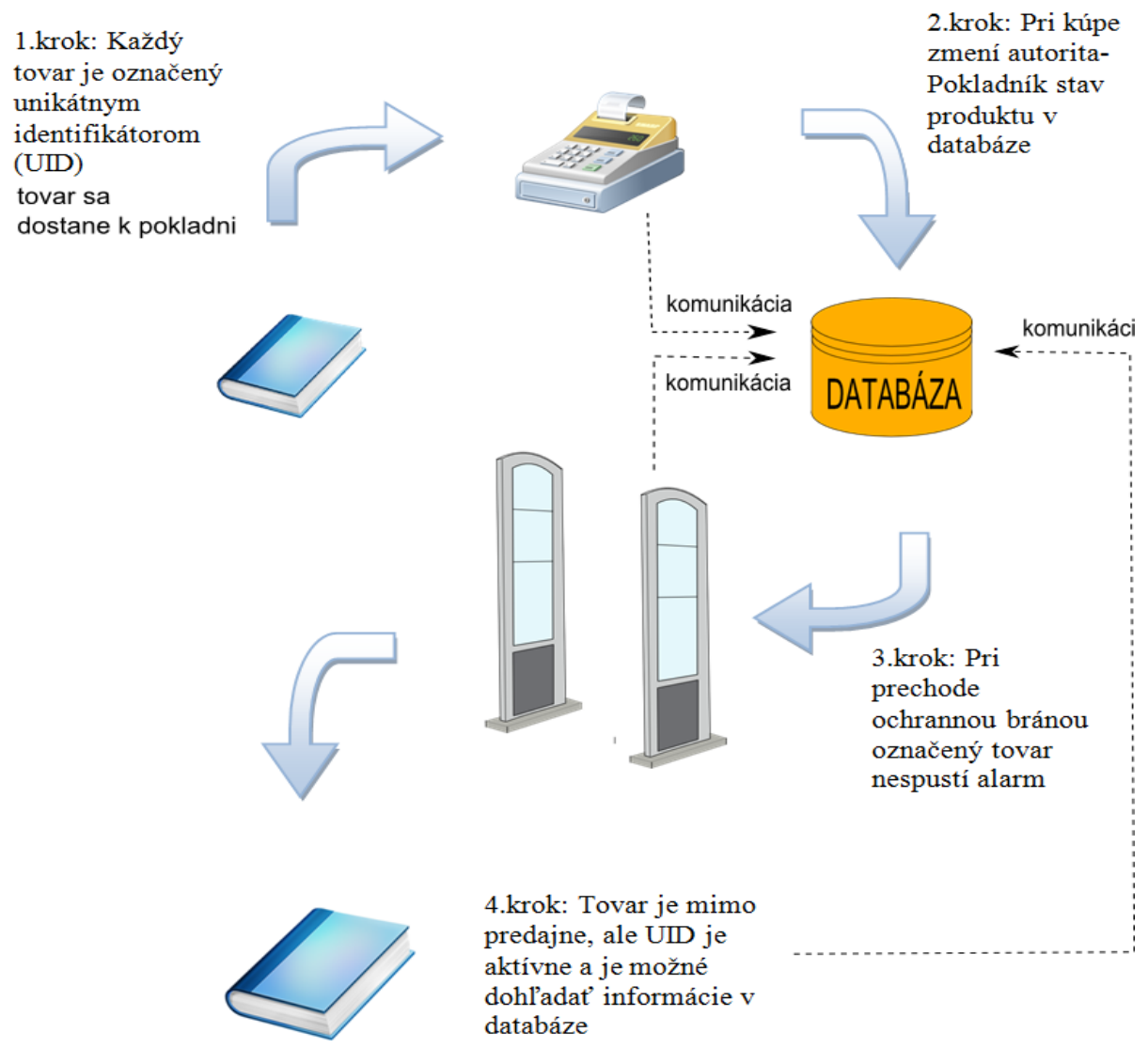

Obrázok 5. Diagram činností modelového príkladu 
Tovar, v grafickom znázornení kniha, má špeciálne identifikačné číslo, pomocou ktorého pristupujeme k údajom o tovare v databáze. V databázy môžu byt' uložené špecifické informácie o tovare vrátene jeho stavu (či sa nachádza v predajni alebo tovar bol predaný). Tento stav sa zmení v druhom kroku, kedy autorita, ktorá má pridelené práva od administrátora databázy, zmení jeho stav po zaplatení. Rozdiel v tret'om kroku oproti súčasnému stavu je, že pri prechode ochrannými bránami (anténami) tieto brány tovar načítajú a komunikujú opät' s databázou. Ak je stav v poriadku poplach sa nespustí. Štítok nie je zničený silným magnetickým pol'om ani odobraný pri pokladni a teda je možné štítok prečítat' a získat' informácie aj po kúpe a vynesení tovaru z predajne.

\section{Literatúra}

[1] EPC [online]. [Cit. 2012-01-09]. Dostupné na internete: http://www.gs1sk.org/elktronicky-produktovykod

[2] The presentation of production line and warehouse management based on RFID technology through 3D modelling and animation [Prezentácia výrobnej linky a skladového hospodárstva založeného na RFID technológii prostredníctvom 3D modelovania a animácie] / Peter Kolarovszki, Vladimír Dúbravka.

In: Transport and telecommunication. - ISSN 1407-6160. - Vol. 11, No. 3 (2010), s. 26-36.

[3] AIDC as a part of the internet of things in enterprise systems [AIDC ako súčast' internetu vecí v podnikových systémoch] / Peter Kolarovszki.

In: CVIS.CZ [elektronický zdroj]. - ISSN 1214-9489. - 2010. - (01.12.2010), [5] s. - Popis urobený 1.7.2011. Požaduje sa Acrobat $\quad$ Reader. $\quad$ Spôsob prístupu: http://www.cvis.cz/eng/hlavni.php?stranka=novinky/clanek.php\&id=76

[4] Vývoj a sestavení jednoduchého identifikáčního systému prostřednictví RFID technologie / Jiří Tengler - Peter Kolarovszki. In: DoNT 2011 [elektronický zdroj] : 3. ročník vedeckej konferencie s medzinárodnou účast’ou ... Žilina, 30. november - 01 december 2011 : zborník prednášok a príspevkov. - Žilina: Žilinská univerzita, 2011. - ISBN 978-80-554-0455-4. - S. 160-169. - Požiadavky na systém: CD-ROM mechanika.

\section{Grantová podpora}

Príspevok je publikovaný v rámci riešenia projektov VEGA 1/1321/12 Výskum nových trendov v manažmente v období globalizácie.

Tato štúdia/publikácia vznikla vd'aka podpore v rámci operačného programu Výskum a vývoj pre projekt: Centrum excelentnosti pre systémy a služby inteligentnej dopravy II., ITMS 26220120050 spolufinancovaný zo zdrojov Európskeho fondu regionálneho rozvoja.

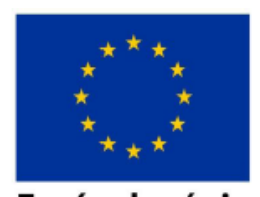

Európska únia

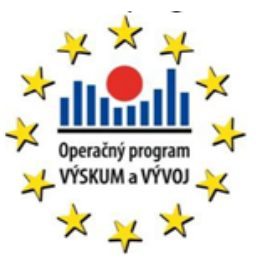

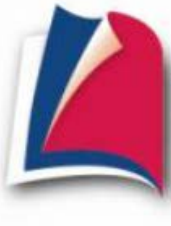

Agentúra

Ministerstva školstva, vedy, výskumu a športu SR pre štrukturálne fondy EÚ

"Podporujeme výskumné aktivity na Slovensku/Projekt je spolufinancovaný zo zdrojov EÚ" 